\title{
STUDI MANFAAT DAYA DUKUNG BELLED PILE DAN MULTI-BELLED PILE
}

\author{
Kevin Septiadi ${ }^{1}$ dan Aniek Prihatiningsih ${ }^{2}$ \\ ${ }^{1}$ Program Studi Sarjana Teknik Sipil, Universitas Tarumanagara, Jl. Letjen S. Parman No.1 Jakarta \\ kevin.325160130@stu.untar.ac.id \\ ${ }^{2}$ Program Studi Sarjana Teknik Sipil, Universitas Tarumanagara, Jl. Letjen S. Parman No.1 Jakarta \\ aniekp@ft.untar.ac.id
}

\begin{abstract}
Foundation is a part of a structure which has a function for to resist and distribute the structure load on it to the soil. In the pile foundation the bearing capacity be affected by skin friction of the pile and end-bearing resistance, therefore one of the alternative for increase bearing capacity of the pile foundation is enlarged base of pile or called belled pile or multi-belled pile. In multi-belled pile enlarge size happen more than once, the enlarge size happen in the hard layer soil so this alternative will be suitable to applied in the soil that have a thin layer hard soil in the middle. In this research will discuss about increase of bearing capacity using belled pile and multibelled pile and comparisson of bored pile with diameter $D$ with belled pile and multi-belled pile with bell diameter $D$ and shaft diameter $3 / 4 D$. Result of research show the increase of bearing capacity biggest happened in multibelled pile with big diameter, bearing capacity increase 42,5\% with the increase of concrete volume 3,3\%. Multibelled pile with bell diameter $1600 \mathrm{~mm}$ and shaft diameter $1200 \mathrm{~mm}$ more efficient compared bored pile without enlarged base with diameter $1600 \mathrm{~mm}$.
\end{abstract}

Keywords: belled pile; multi-belled pile; bore pile; bearing capacity; enlarged base

\begin{abstract}
ABSTRAK
Fondasi adalah sebuah bagian dari stukrtur yang berfungsi untuk menahan dan menyalurkan beban bangunan yang ada diatasnya ke tanah. Pada fondasi tiang daya dukung fondasi dipengaruhi oleh gesekan selimut tiang dan tahanan ujung tiang sehingga salah satu cara untuk meningkatkan daya dukung fondasi adalah dengan memperbesar ujung tiang atau disebut belled pile atau multi-belled pile. Pada multi-belled pile perbesaran penampang terjadi lebih dari satu kali yaitu pada lapisan tanah keras sehingga sangat cocok untuk diaplikasikan pada lapisan tanah yang memiliki lapisan keras tipis di bagian tengah. Pada penulisan ini akan dibahas mengenai peningkatan daya dukung tiang menggunakan belled pile dan multi-belled pile serta perbandingan daya dukung tiang bor diameter $\mathrm{D}$ dengan belled pile dan multi-belled pile yang memiliki diameter bel sebesar D dan diameter tiang sebesar $3 / 4 \mathrm{D}$. Hasil penelitian menunjukkan peningkatan daya dukung terbesar terjadi pada multi-belled pile dengan diameter besar, daya dukung meningkat sebesar 42,5\% dengan peningkatan volume beton sebesar 3,3\%. Pengunaan multi-belled pile dengan diameter bel sebesar $1600 \mathrm{~mm}$ dan diameter selimut sebesar $1200 \mathrm{~mm}$ lebih efisien dibandingkan tiang bor tanpa pembesaran dengan diameter $1600 \mathrm{~mm}$.
\end{abstract}

Kata kunci: belled pile; multi-belled pile; tiang bor; daya dukung; ujung tiang diperbesar

\section{PENDAHULUAN}

Pertumbuhan jumlah penduduk di Indonesia membuat peningkatan kebutuhan infrastruktur seperti jembatan, jalan raya, rumah tinggal dan lain-lain sehingga membuat pemerintah terus meningkatkan infrastruktur yang ada agar dapat memenuhi kebutuhan semua penduduk. Untuk memenuhi kebutuhan infrastruktur tersebut maka pembangunan infrastruktur harus dilakukan dengan baik dan benar sesuai dengan standar yang ada.

Fondasi merupakan salah satu dari pekerjaan tanah yang sangat penting dalam sebuah struktur bangunan karena memiliki fungsi untuk menopang dan menyalurkan beban bangunan yang ada di atasnya. Secara umum fondasi dibagi menjadi dua, yaitu fondasi dangkal dan fondasi dalam. Untuk bangunan tinggi fondasi yang umumnya dipakai adalah jenis fondasi dalam yaitu fondasi.

Berdasarkan pelaksanaan di lapangan fondasi tiang dibagi menjadi fondasi tiang pancang dan fondasi tiang bor. Tiang pancang dan fondasi tiang bor memiliki kelebihan dan kekurangannya masing-masing sehingga pemilihan 
jenis fondasi tiang disesuaikan dengan kondisi lapangan. Tiang yang digunakan harus mampu menahan beban bangunan yang ada di atasnya. Kemampuan fondasi menahan beban bangunan disebut daya dukung fondasi, sehingga daya dukung fondasi tidak boleh lebih kecil dari beban bangunan yang ditahan fondasi.

Semakin besar beban bangunan yang ditahan fondasi maka semakin besar daya dukung fondasi tiang yang dibutuhkan. Daya dukung tiang dipengaruhi oleh gesekan selimut dan tahanan ujung tiang. Sehingga untuk meningkatkan daya dukung tiang, alternatif yang dapat digunakan adalah dengan memperbesar ukuran penampang ujung tiang atau yang dikenal dengan belled pile.

Dalam penelitian ini, penulis akan meneliti mengenai manfaat pengunaan belled pile dan multi-belled pile terhadap daya dukung tiang. Selain itu penulis akan membandingkan efisiensi pengunaan belled pile dan multi-belled pile dengan fondasi tiang bor biasa.

Batasan-batasan masalah pada penelitian ini adalah sebagai berikut:

1. Parameter tanah yang digunakan berdasarkan hasil uji laboratorium dan uji lapangan,

2. Kekuatan bahan tiang diabaikan,

3. Gaya lateral dan gaya gempa diabaikan,

4. Pembahasan tidak mencakup pembesian fondasi,

5. Fondasi dianggap tidak memiliki kemiringan,

6. Pembahasan tidak mencakup penurunan fondasi.

Berdasarkan uraian yang sudah disebutkan sebelumnya, masalah yang harus diselesaikan yaitu:

1. Daya dukung tiang menggunakan fondasi tiang bor tanpa pembesaran,

2. Daya dukung tiang menggunakan fondasi tiang dengan pembesaran (belled pile),

3. Daya dukung tiang menggunakan fondasi tiang dengan lebih dari satu pembesaran (multi-belled pile),

4. Efisiensi penggunaan belled pile dan multi-belled pile dibandingkan dengan fondasi tiang bor biasa.

Berdasarkan rumusan masalah yang ada, maka tujuan penelitian ini adalah sebagai berikut:

1. Mengetahui perilaku daya dukung fondasi tiang bor tanpa pembesaran,

2. Mengetahui perilaku daya dukung fondasi tiang dengan pembesaran (belled pile),

3. Mengetahui perilaku daya dukung fondasi tiang dengan lebih dari satu pembesaran (multi-belled pile),

4. Mengetahui seberapa efisien pengunaan belled pile dan multi belled pile dibandingkan dengan fondasi tiang bor biasa.

\section{Fondasi tiang bor}

Fondasi Tiang bor merupakan fondasi tiang yang dibuat dengan melakukan pengeboran pada tanah sehingga berbentuk seperti cetakan tiang lalu memasukkan tulangan baja dan beton siap cetak ke dalamnya. Pada pelaksanaannya fondasi tiang bor tidak menimbulkan getaran dan kegaduhan sehingga cocok untuk digunakan pada daerah yang padat penduduk tetapi waktu yang dibutuhkan untuk membuat fondasi tiang bor lebih lama dibandingkan menggunakan tiang pancang.

\section{Belled pile}

Belled pile didefinisikan sebagai sebuah konstruksi yang terbuat dari beton yang didesain untuk meningkatkan daya dukung pada sebuah fondasi tiang bor. Peningkatan diameter dari pile secara efektif dapat meningkatkan daya dukung dari pile. Belled pile berbentuk tiang lurus dengan bagian bawah berbentuk bel. Belled pile juga didefinisikan sebagai konstruksi tiang beton yang dicetak di lapangan dengan satu atau lebih perbesaran pada lapisan tanah kohesif keras seperti yang ditunjukkan pada Gambar 1. Tiang yang memiliki lebih dari satu pembesaran disebut dengan multi-belled pile. Kekurangan dari belled pile adalah instalasi yang lebih rumit dibandingkan dengan tiang bor biasa. Pada saat dilakukan pengeboran untuk bagian bel perlu digunakan bentonit agar tanah yang sudah dibor tidak mengalami keruntuhan. Perbedaan fondasi tiang lurus dengan belled pile dapat dilihat pada Gambar 2. 


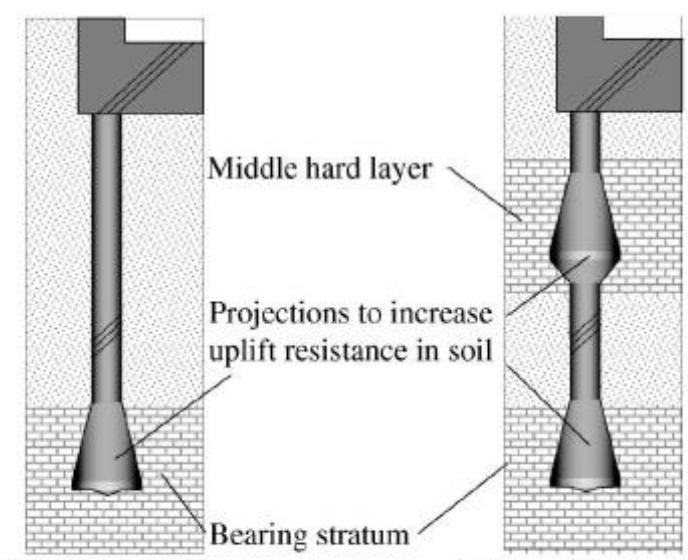

$\begin{array}{ll}\text { (a) A belled pile } & \text { (b) A multi-belled pile }\end{array}$

Gambar 1. Belled pile dan multi-belled pile (Sumber: Honda, 2011)

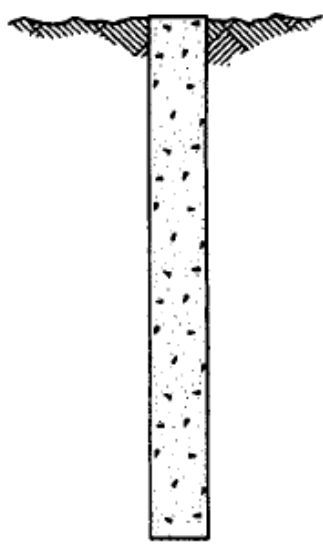

(a)

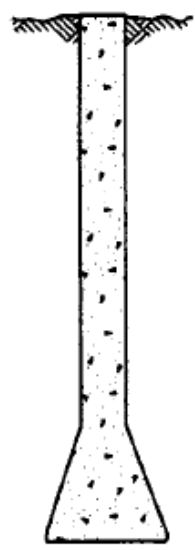

(b)

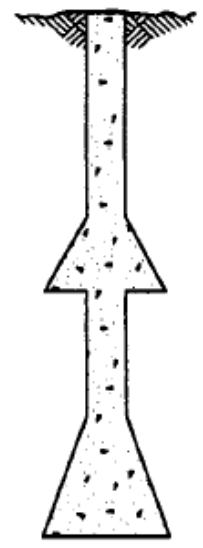

(c)

Gambar 2. Tipe tiang bor: (a) tiang lurus; (b) belled pile; (c) multi-belled pile

(Sumber: Prakash dan Sharma, 1898)

Selama beberapa tahun sebelumnya, banyak penelitian yang sudah dilakukan mengenai belled pile. (Yang, dkk. 2018) mengatakan peningkatan panjang tiang membuat pengaruh bel menjadi lebih kecil. (Lin, dkk, 2015) mengatakan semakin padat tanah pada dasar fondasi maka semakin besar daya dukung belled pile. (Kong, 2011) mengatakan bahwa pada wedge belled pile dan belled pile penurunan yang terjadi lebih kecil dibandingkan dengan tiang jenis lainnya serta daya dukung dari wedge belled pile group meningkat berdasarkan jarak, diameter bel dan kekakuan tanah.

Pada instalasi belled pile digunakan mata bor khusus yang biasa disebut belling bucket. Instalasi belled pile dilakukan dengan melakukan pengeboran tanah sampai kedalaman yang diinginkan. Setelah itu belling bucket digunakan untuk memperluas lebar ujung tiang sesuai yang diinginkan. Setelah lebar yang diinginkan tercapai alat bor diangkat dan dimasukkan tulangan baja ke dalam lubang lalu beton siap cetak dituang ke dalam lubang. Bentuk dari belling bucket dapat dilihat pada Gambar 3. 


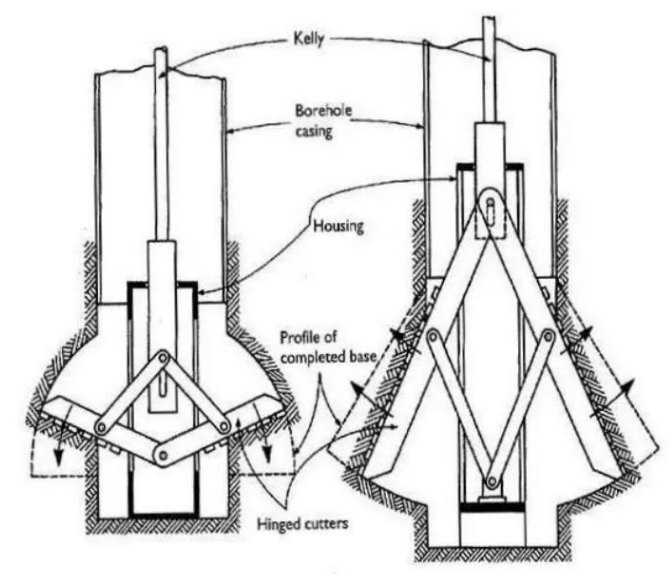

Gambar 3. Belling bucket (sumber: Franki Foundation (2020))

\section{Daya dukung fondasi tiang}

Daya dukung tiang dapat dihitung dengan menjumlahkan tahanan ujung tiang dengan gesekan selimut tiang. Sehingga daya dukung tiang dapat didefinisikan seperti pada persamaan berikut.

$$
\mathrm{Q}_{\mathrm{all}}=\frac{\mathrm{Q}_{\mathrm{p}}}{\mathrm{SF}}+\frac{\mathrm{Q}_{\mathrm{s}}}{\mathrm{SF}}-\mathrm{W}_{\mathrm{p}}
$$

dengan $\mathrm{Q}_{\text {all }}=$ daya dukung izin, $\mathrm{Q}_{\mathrm{p}}=$ daya dukung ujung tiang, $\mathrm{Q}_{\mathrm{s}}=$ daya dukung selimut tiang, $\mathrm{SF}=$ faktor keamanan, $\mathrm{W}_{\mathrm{p}}=$ berat tiang.

Tahanan ujung tiang dapat dihitung dengan mengembangkan persamaan fondasi dangkal. Dengan mengganti notasi lebar fondasi menjadi diameter tiang maka persamaan tahanan ujung fondasi tiang adalah sebagai berikut.

$$
\mathrm{Q}_{\mathrm{p}}=\mathrm{A}\left[\mathrm{S}_{\mathrm{u}} \mathrm{N}_{\mathrm{c}}^{\prime}+\eta \mathrm{qN} \mathrm{N}_{\mathrm{q}}^{\prime}+\frac{1}{2} \gamma \mathrm{DN} \mathrm{N}_{\gamma}^{\prime}\right]
$$

dengan $\mathrm{Q}_{\mathrm{p}}=$ daya dukung ujung tiang, $\mathrm{S}_{\mathrm{u}}=$ undrained shear strength, $\mathrm{N}_{\mathrm{c}}^{\prime}, \mathrm{N}_{\mathrm{q}}^{\prime}, \mathrm{N}_{\gamma}^{\prime}=$ faktor kapasitas dukung, $\mathrm{q}=$ tekanan overburden pada dasar fondasi, $\gamma=$ berat jenis tanah, $\mathrm{D}=$ diameter tiang.

Sedangkan daya dukung selimut tiang dapat dituliskan dalam persamaan sebagai berikut.

$$
\mathrm{Q}_{\mathrm{s}}=\mathrm{P} \Sigma \Delta \mathrm{Lf}_{\mathrm{s}}
$$

Dengan,

$$
\mathrm{f}_{\mathrm{s}}=\alpha \mathrm{S}_{\mathrm{u}}
$$

dengan $\mathrm{Q}_{\mathrm{s}}=$ daya dukung selimut,, $\mathrm{P}=$ keliling tiang, $\Delta \mathrm{L}=$ panjang tiang, $\mathrm{f}_{\mathrm{s}}=$ gesekan selimut, $\alpha=$ koefisien adhesi tanah dan tiang (Gambar 4), $\mathrm{S}_{\mathrm{u}}=$ undrained shear strength.

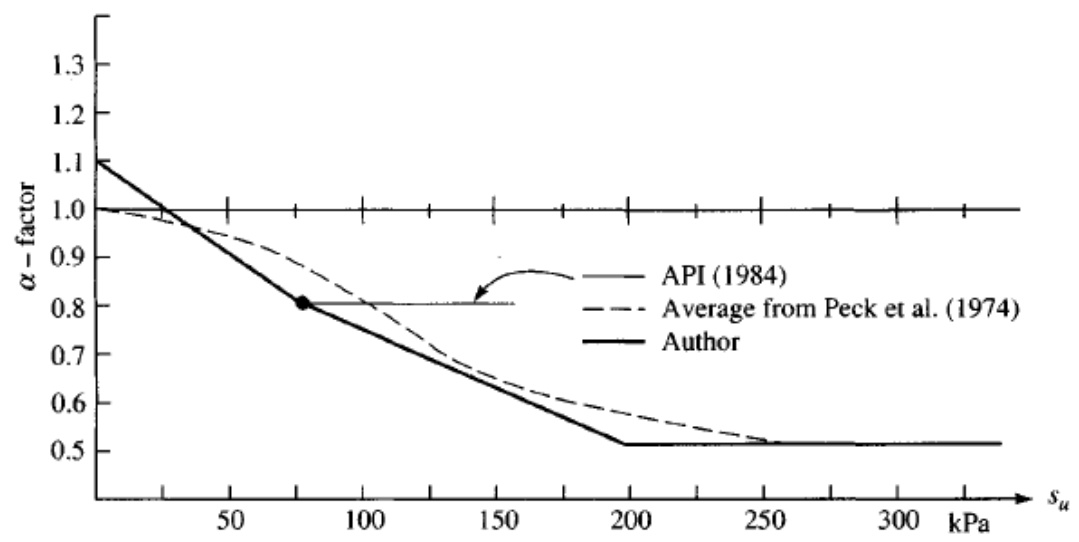

Gambar 4. Hubungan koefisien $\alpha$ dan $\mathrm{S}_{\mathrm{u}}$ (Sumber: Bowles, 1996) 


\section{Daya dukung belled pile}

Sama halnya dengan tiang bor biasa, daya dukung belled pile didapatkan berdasarkan daya dukung ujung tiang dan daya dukung selimut tiang. Apabila pembesaran tiang terjadi di ujung tiang maka daya dukung ujung tiang belled pile dapat dihitung menggunakan persamaan (5) sedangkan apabila pembesaran terjadi pada bagian tengah tiang, daya dukung akibat pembesaran (bel) dapat dihitung menggunakan persamaan (6).

$$
\begin{gathered}
\mathrm{Q}_{\mathrm{p}}=\frac{1}{4} \pi \mathrm{D}_{\mathrm{b}}^{2}\left[\mathrm{~S}_{\mathrm{u}} \mathrm{N}_{\mathrm{c}}^{\prime}+\eta \mathrm{qN}_{\mathrm{q}}^{\prime}+\frac{1}{2} \gamma \mathrm{D}_{\mathrm{b}} \mathrm{N}_{\gamma}^{\prime}\right] \\
\mathrm{Q}_{\mathrm{p}}=\frac{1}{4} \pi\left(\mathrm{D}_{\mathrm{b}}^{2}-\mathrm{D}_{\mathrm{s}}^{2}\right)\left[\mathrm{S}_{\mathrm{u}} \mathrm{N}_{\mathrm{c}}^{\prime}+\eta \mathrm{qN}_{\mathrm{q}}^{\prime}+\frac{1}{2} \gamma\left(\mathrm{D}_{\mathrm{b}}-\mathrm{D}_{\mathrm{s}}\right) \mathrm{N}_{\gamma}^{\prime}\right]
\end{gathered}
$$

dengan $\mathrm{Q}_{\mathrm{p}}=$ daya dukung ujung tiang,, $\mathrm{S}_{\mathrm{u}}=$ undrained shear strength, $\mathrm{N}_{\mathrm{c}}^{\prime}, \mathrm{N}_{\mathrm{q}}^{\prime}, \mathbf{N}_{\gamma}^{\prime}=$ faktor kapasitas dukung, $\mathrm{q}=$ tekanan overburden pada dasar fondasi, $\gamma=$ berat jenis tanah, $\mathrm{D}_{\mathrm{b}}=$ diameter bel, $\mathrm{D}_{\mathrm{s}}=$ diameter selimut tiang.

Daya dukung selimut tiang dapat dihitung dengan menjumlahkan daya dukung selimut tiang dan daya dukung selimut bel. Parameter desain untuk gesekan selimut bel dapat dilihat pada tabel 1. Daya dukung selimut belled pile dapat dihitung menggunakan persamaan (7).

$$
\mathrm{Q}_{\mathrm{s}}=\sum \pi \mathrm{D}_{\mathrm{s}} \Delta \mathrm{Lf} \mathrm{f}_{\mathrm{s}}+\sum \pi\left(\frac{\mathrm{D}_{\mathrm{b}}+\mathrm{D}_{\mathrm{s}}}{2}\right) \Delta \mathrm{Lf}_{\mathrm{s}}
$$

dengan $\mathrm{Q}_{\mathrm{s}}=$ daya dukung selimut, $\mathrm{D}_{\mathrm{b}}=$ diameter bel, $\mathrm{D}_{\mathrm{s}}=$ diameter selimut tiang, $\Delta \mathrm{L}=$ panjang tiang, $\mathrm{f}_{\mathrm{s}}=$ gesekan selimut.

Tabel 1. Parameter desain gesekan selimut bel

\begin{tabular}{lc}
\hline \multicolumn{1}{c}{ Desain Category } & $\mathrm{C}_{\mathrm{A}} / \mathrm{C}$ \\
\hline Belled shaft installed dry or by slurry displacement methods with no soil of & 0,3 \\
exceptional stiffness below the base & 0,15 \\
Belled Shaft installed with drilling mud along some portion of the hole possible \\
below the base
\end{tabular}

(Sumber: NAFVAC, 1986)

Apabila tiang memiliki lebih dari satu pembesaran (multi-belled pile) maka daya dukung tiang didapatkan berdasarkan total daya dukung tiap pembesaran dan daya dukung selimut tiang seperti yang tunjukkan pada persamaan (8).

$$
\mathrm{Q}_{\mathrm{all}}=\frac{\mathrm{Q}_{\mathrm{p} 1}+\mathrm{Q}_{\mathrm{p} 2}+\mathrm{Q}_{\mathrm{s}}}{\mathrm{SF}}-\mathrm{W}_{\mathrm{p}}
$$

Dengan $\mathrm{Q}_{\text {all }}=$ daya dukung izin, $\mathrm{Q}_{\mathrm{p} 1}=$ daya dukung ujung tiang, $\mathrm{Q}_{\mathrm{p} 2}=$ daya dukung akibat pembesaran pada bagian tengah tiang, $\mathrm{Q}_{\mathrm{s}}=$ daya dukung selimut, $\mathrm{SF}=$ faktor keamanan.

\section{METODE PENELITIAN}

\section{Pengumpulan data}

Pada kajian teknis kali ini data yang digunakan pada penelitian berasal dari data tanah sebuah proyek yang ada di Jakarta. Data yang dikumpulkan berdasarkan hasil dari uji lapangan dengan uji SPT (Standart Penetration Test)) dan hasil uji laboratorium.

\section{Pengolahan data}

Setelah data-data yang diperlukan sudah terkumpul, selanjutnya dilakukan pengolahan data. Pada tahap ini data diolah untuk mendapatkan berbagai parameter yang digunakan berdasarkan studi literatur yang sudah dilakukan sehingga dapat dilakukan analisis daya dukung pada fondasi tiang bor biasa, belled pile dan multi-belled pile. Setelah analisis daya dukung dilakukan maka dilanjutkan dengan membandingkan hasil analisis daya dukung dan 
volume beton yang digunakan pada fondasi tiang bor biasa, belled pile dan multi-belled pile untuk mengetahui bagaimana peningkatan daya dukung pada belled pile dan multi-belled pile dan melihat apakah belled pile dan multi-belled pile dengan diameter bel sebesar D dan diameter selimut bel sebesar 3/4 D lebih efisien dibandingkan dengan tiang bor tanpa pembesaran dengan diameter sebesar $\mathrm{D}$.

\section{Diagram alir penelitian}

Adapun diagram alir pada penelitian kali ini ditunjukkan pada Gambar 5.

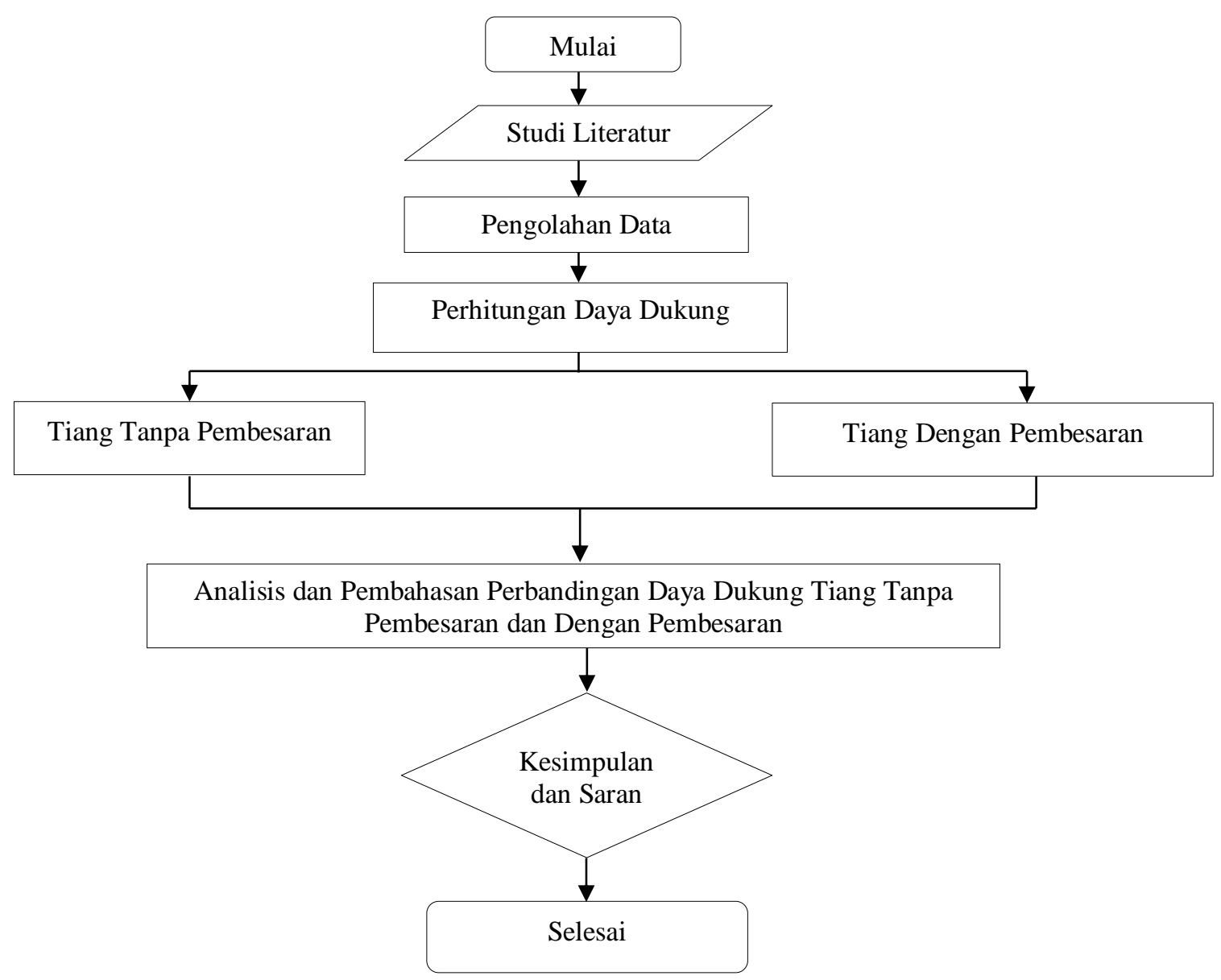

Gambar 5. Diagram alir penelitian

\section{HASIL DAN PEMBAHASAN}

Tiang yang digunakan pada penelitian ini adalah tiang bor. Tiang bor yang digunakan dibagi menjadi empat jenis yaitu:

1. Tiang bor tanpa pembesaran,

2. Belled pile (pembesaran di tengah tiang),

3. Belled pile (pembesaran di ujung tiang),

4. Multi-belled pile (pembesaran di ujung dan tengah tiang).

Pada penelitian ini tiang dipasang sampai kedalaman 27 meter. Pada tiang dengan belled pile dengan pembesaran di tengah tiang, perbesaran terjadi pada kedalaman 12 meter. Sketsa gambar empat jenis tiang yang digunakan dapat dilihat pada Gambar 6 . 


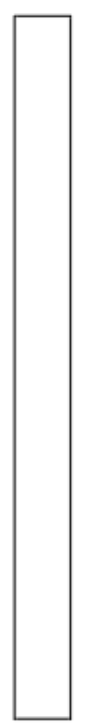

(1)

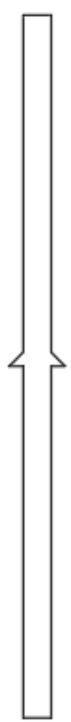

(2)

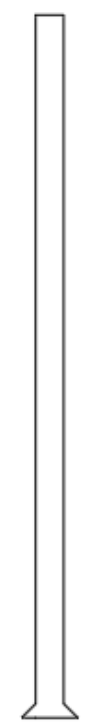

(3)

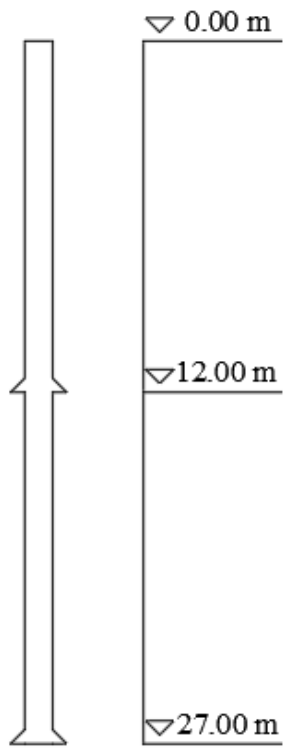

(4)

Gambar 6. Sketsa jenis tiang bor

Analisis daya dukung empat jenis tiang bor tersebut menggunakan 3 kategori ukuran tiang. Kategori ukuran tersebut adalah tiang dengan diameter kecil, tiang dengan diameter sedang dan tiang dengan diameter besar. Tiang tanpa pembesaran pada masing-masing kategori menggunakan diameter sebesar D sedangkan pada tiang bor dengan pembesaran (belled pile) menggunakan diameter selimut tiang sebesar 3/4D dan diameter bel sebesar D.

\section{Parameter tanah}

Untuk melakukan analisis daya dukung tiang diperlukan data parameter tanah. Penentuan parameter tanah dilakukan dengan melakukan korelasi berdasarkan data tanah dan mengacu pada tinjauan pustaka. Adapun parameter tanah yang digunakan pada penelitian ini adalah sebagai berikut.

Tabel 2. Parameter tanah yang digunakan

\begin{tabular}{cccccccc}
\hline $\begin{array}{c}\text { Kedalaman } \\
(\mathrm{m})\end{array}$ & Jenis tanah & $\mathrm{S}_{\mathrm{u}}\left(\mathrm{kN} / \mathrm{m}^{2}\right)$ & $\mathrm{c}\left(\mathrm{kN} / \mathrm{m}^{2}\right)$ & $\gamma\left(\mathrm{kN} / \mathrm{m}^{3}\right)$ & $\phi\left(^{\circ}\right)$ & $\mathrm{e}$ & $\mathrm{E}_{\mathrm{s}}\left(\mathrm{kN} / \mathrm{m}^{2}\right)$ \\
\hline $0-4$ & Silty clay & 42 & 83 & 16,3 & 0 & 0,65 & 28000 \\
$4-7$ & Clayey Silt & 32 & 63 & 14,7 & 0 & 0,90 & 19000 \\
$7-11$ & Silty Sand & 45 & 90 & 15,6 & 0 & 0,65 & 15000 \\
$11-13$ & Clayey Silt & 152 & 304 & 16,1 & 0 & 0,60 & 50000 \\
$13-19$ & Clayey Silt & 85 & 169 & 14,0 & 0 & 0,60 & 43000 \\
$19-23$ & Sandy Silt & 330 & 660 & 17,7 & 31 & 0,63 & 75000 \\
$23-26$ & Silty Sand & 218 & 435 & 17,0 & 0 & 0,65 & 38000 \\
$26-29$ & Silt & 330 & 660 & 17,9 & 0 & 0,60 & 75000 \\
$29-37$ & Clayey Silt & 291 & 582 & 17,5 & 0 & 0,60 & 70000 \\
$37-43$ & Sandy Silt & 270 & 540 & 18,2 & 31 & 0,40 & 52000 \\
$43-45$ & Sand & 338 & 677 & 18,8 & 31 & 0,45 & 71000 \\
\hline
\end{tabular}

\section{Analisis peningkatan daya dukung tiang diameter kecil}

Pada kategori tiang diameter kecil, peningkatan daya dukung tiang akibat pembesaran ujung tiang dilakukan dengan membandingkan daya dukung tiang bor tanpa pembesaran diameter $300 \mathrm{~mm}$ dengan belled pile dan multi- 
belled pile yang memiliki diameter bel sebesar $400 \mathrm{~mm}$ dan diameter selimut bel sebesar $300 \mathrm{~mm}$. Sketsa ukuran tiang diameter kecil dapat dilihat pada gambar 7 .

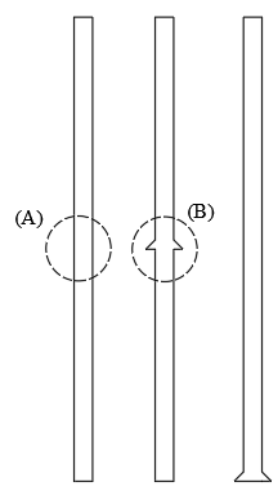

(1) (2)
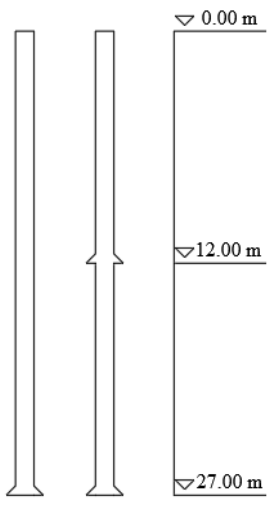
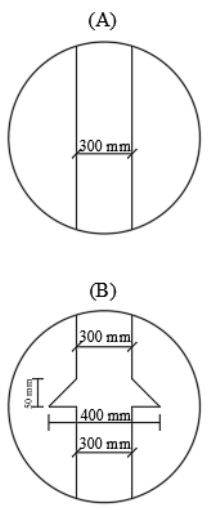

Gambar 7. Sketsa ukuran tiang diameter kecil

Hasil analisis peningkatan daya dukung belled pile dan multi-belled pile dapat dilihat pada tabel 3.

Tabel 3. Hasil analisis peningkatan daya dukung belled pile dan multi-belled pile tiang diameter kecil

\begin{tabular}{ccccc}
\hline Jenis tiang & $\begin{array}{c}\text { Volume beton } \\
\left(\mathrm{m}^{3}\right)\end{array}$ & $\begin{array}{c}\text { Daya dukung } \\
(\mathrm{kN})\end{array}$ & $\begin{array}{c}\text { \% Daya dukung } \\
\text { tercapai }\end{array}$ & $\begin{array}{c}\text { \% Beton yang } \\
\text { digunakan }\end{array}$ \\
\hline $\begin{array}{c}\text { Tiang Tanpa Pembesaran } \\
\text { Belled Pile (Pembesaran di } \\
\text { tengah tiang) }\end{array}$ & 1,9093 & 742,402 & 100,0 & 100 \\
$\begin{array}{c}\text { Belled Pile (Pembesaran di } \\
\text { ujung tiang) }\end{array}$ & 1,9099 & 766,578 & 103,3 & 100,031 \\
Multi-Belled Pile & 1,9099 & 794,671 & 107,0 & 100,031 \\
\hline
\end{tabular}

\section{Analisis peningkatan daya dukung tiang diameter sedang}

Pada kategori tiang diameter kecil, peningkatan daya dukung tiang akibat pembesaran ujung tiang dilakukan dengan membandingkan daya dukung tiang bor tanpa pembesaran diameter $600 \mathrm{~mm}$ dengan belled pile dan multibelled pile yang memiliki diameter bel sebesar $800 \mathrm{~mm}$ dan diameter selimut bel sebesar $600 \mathrm{~mm}$. Sketsa ukuran tiang diameter kecil dapat dilihat pada gambar 8.

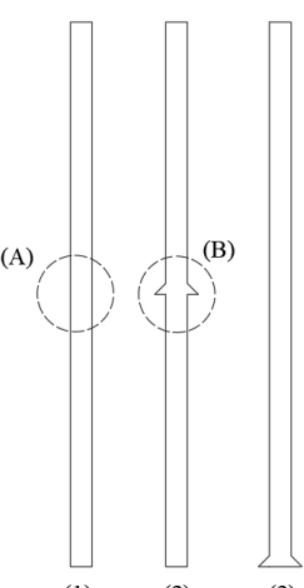

(1)
(3)

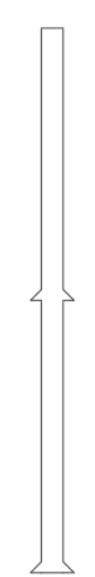

(4)
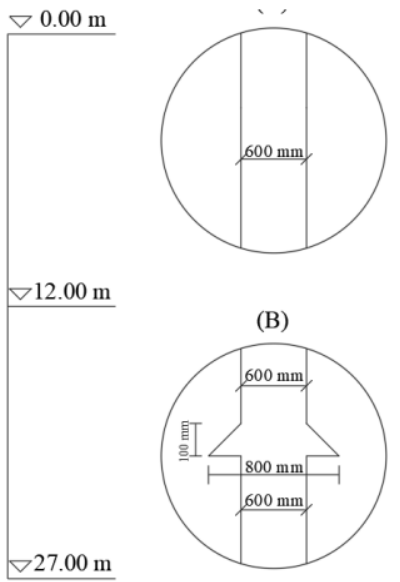

(B)

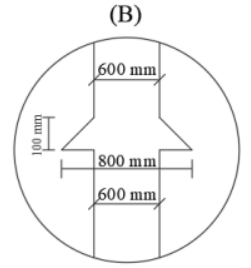

Gambar 8. Sketsa ukuran tiang diameter sedang 
Hasil analisis peningkatan daya dukung belled pile dan multi-belled pile dapat dilihat pada tabel 4.

Tabel 4. Hasil analisis peningkatan daya dukung belled pile dan multi-belled pile tiang diameter sedang

\begin{tabular}{ccccc}
\hline Jenis tiang & $\begin{array}{c}\text { Volume beton } \\
\left(\mathrm{m}^{3}\right)\end{array}$ & $\begin{array}{c}\text { Daya dukung } \\
(\mathrm{kN})\end{array}$ & $\begin{array}{c}\text { \% Daya dukung } \\
\text { tercapai }\end{array}$ & $\begin{array}{c}\text { \% Beton yang } \\
\text { digunakan }\end{array}$ \\
\hline $\begin{array}{c}\text { Tiang Tanpa Pembesaran } \\
\text { Belled Pile (Pembesaran di } \\
\text { tengah tiang) }\end{array}$ & 7,64 & 1537,5859 & 100,0 & 100 \\
$\begin{array}{c}\text { Belled Pile (Pembesaran di } \\
\text { ujung tiang) }\end{array}$ & 7,6451 & 1635,811 & 106,4 & 100,066 \\
Multi-Belled Pile & 7,6984 & 1751,746 & 113,9 & 100,066 \\
\hline
\end{tabular}

\section{Analisis peningkatan daya dukung tiang diameter besar}

Pada kategori tiang diameter kecil, peningkatan daya dukung tiang akibat pembesaran ujung tiang dilakukan dengan membandingkan daya dukung tiang bor tanpa pembesaran diameter $1200 \mathrm{~mm}$ dengan belled pile dan multi-belled pile yang memiliki diameter bel sebesar $1600 \mathrm{~mm}$ dan diameter selimut bel sebesar $1200 \mathrm{~mm}$. Sketsa ukuran tiang diameter kecil dapat dilihat pada gambar 9.

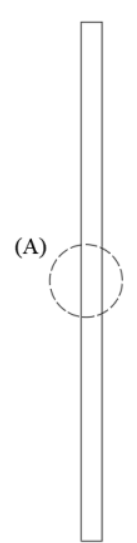

(1) (2)

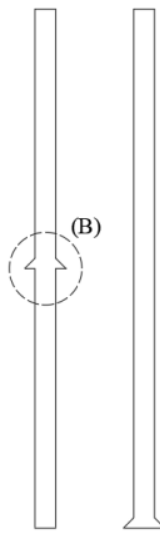

(3)

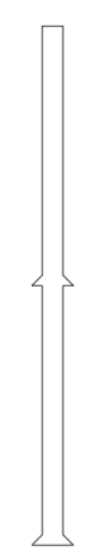

(4)
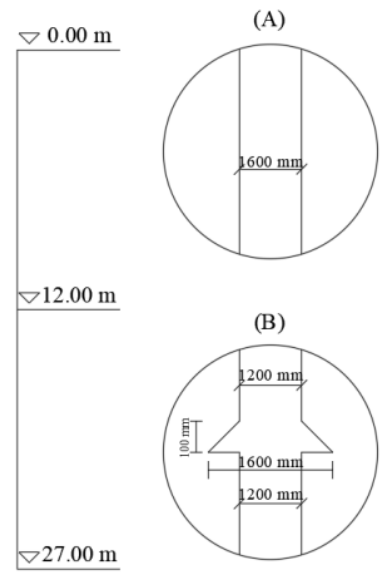

Gambar 9. Sketsa ukuran tiang diameter kecil

Hasil analisis peningkatan daya dukung belled pile dan multi-belled pile dapat dilihat pada tabel 5.

Tabel 5. Hasil analisis peningkatan daya dukung belled pile dan multi-belled pile tiang diameter besar

\begin{tabular}{|c|c|c|c|c|}
\hline Jenis tiang & $\begin{array}{l}\text { Volume beton } \\
\qquad\left(\mathrm{m}^{3}\right)\end{array}$ & $\begin{array}{c}\text { Daya dukung } \\
(\mathrm{kN})\end{array}$ & $\begin{array}{c}\% \text { Daya dukung } \\
\text { tercapai }\end{array}$ & $\begin{array}{c}\% \text { Beton yang } \\
\text { digunakan }\end{array}$ \\
\hline Tiang Tanpa Pembesaran & 30,54 & 3463,427 & 100,0 & 100 \\
\hline $\begin{array}{l}\text { Belled Pile (Pembesaran di } \\
\text { tengah tiang) }\end{array}$ & 30,6242 & 3914,013 & 113,0 & 100,3 \\
\hline $\begin{array}{c}\text { Belled Pile (Pembesaran di } \\
\text { ujung tiang) }\end{array}$ & 30,6242 & 4475,620 & 129,2 & 100,3 \\
\hline Multi-Belled Pile & 31,5396 & 4934,888 & 142,5 & 103,3 \\
\hline
\end{tabular}

\section{Analisis perbandingan daya dukung tiang diameter kecil}

Analisis perbandingan daya dukung tiang dilakukan dengan membandingkan daya dukung tiang bor tanpa pembesaran diameter sebesar $\mathrm{D}$ dengan belled pile dan multi-belled pile yang memiliki diameter bel sebesar $\mathrm{D}$ dan selimut tiang sebesar $3 / 4$ D. Pada kategori ukuran diameter kecil, tiang tanpa pembesaran menggunakan diameter $400 \mathrm{~mm}$ sedangkan pada tiang dengan pembesaran (belled pile) menggunakan diameter selimut tiang sebesar 300 $\mathrm{mm}$ dan diameter bel sebesar $400 \mathrm{~mm}$. Hasil analisis dan perbandingan daya dukung tiang diameter kecil dapat dilihat pada tabel 6 . 
Tabel 6. Hasil analisis dan perbandingan daya dukung tiang diameter kecil

\begin{tabular}{ccccc}
\hline Jenis tiang & $\begin{array}{c}\text { Volume beton } \\
\left(\mathrm{m}^{3}\right)\end{array}$ & $\begin{array}{c}\text { Daya dukung } \\
(\mathrm{kN})\end{array}$ & $\begin{array}{c}\text { \% Daya dukung } \\
\text { tercapai }\end{array}$ & $\begin{array}{c}\text { \% Beton yang } \\
\text { digunakan }\end{array}$ \\
\hline $\begin{array}{c}\text { Tiang Tanpa Pembesaran } \\
\text { Belled Pile (Pembesaran di } \\
\text { tengah tiang) }\end{array}$ & 3,943 & 993,371 & 100,0 & 100 \\
$\begin{array}{c}\text { Belled Pile (Pembesaran di } \\
\text { ujung tiang) }\end{array}$ & 1,9099 & 766,578 & 77,2 & 56,3 \\
Multi-Belled Pile & 1,9099 & 794,671 & 80,0 & 56,3 \\
\hline
\end{tabular}

Analisis perbandingan daya dukung tiang diameter sedang

Analisis perbandingan daya dukung tiang dilakukan dengan membandingkan daya dukung tiang bor tanpa pembesaran diameter sebesar D dengan belled pile dan multi-belled pile yang memiliki diameter bel sebesar D dan selimut tiang sebesar $3 / 4$ D. Pada kategori tiang diameter sedang, tiang bor tanpa pembesaran menggunakan diameter sebesar $800 \mathrm{~mm}$ sedangkan tiang dengan pembesaran menggunakan diameter selimut tiang sebesar 600 $\mathrm{mm}$ dan diameter bel sebesar $800 \mathrm{~mm}$. Hasil analisis dan perbandingan daya dukung tiang diameter sedang dapat dilihat pada tabel 7 .

Tabel 7. Hasil analisis dan perbandingan daya dukung tiang diameter sedang

\begin{tabular}{ccccc}
\hline Jenis tiang & $\begin{array}{c}\text { Volume beton } \\
\left(\mathrm{m}^{3}\right)\end{array}$ & $\begin{array}{c}\text { Daya dukung } \\
(\mathrm{kN})\end{array}$ & $\begin{array}{c}\text { \% Daya dukung } \\
\text { tercapai }\end{array}$ & $\begin{array}{c}\text { \% Beton yang } \\
\text { digunakan }\end{array}$ \\
\hline $\begin{array}{c}\text { Tiang Tanpa Pembesaran } \\
\text { Belled Pile (Pembesaran di } \\
\text { tengah tiang) }\end{array}$ & 13,58 & 2099,1316 & 100,0 & 100 \\
$\begin{array}{c}\text { Belled Pile (Pembesaran di } \\
\text { ujung tiang) }\end{array}$ & 7,65 & 1635,811 & 77,9 & 56,3 \\
Multi-Belled Pile & 7,65 & 1751,746 & 83,5 & 56,3 \\
\hline
\end{tabular}

\section{Analisis perbandingan daya dukung tiang diameter besar}

Analisis perbandingan daya dukung tiang dilakukan dengan membandingkan daya dukung tiang bor tanpa pembesaran diameter sebesar D dengan belled pile dan multi-belled pile yang memiliki diameter bel sebesar D dan selimut tiang sebesar $3 / 4$ D. Kategori ukuran tiang terakhir yaitu tiang diameter besar. Tiang bor tanpa pembesaran yang digunakan memiliki diameter $1600 \mathrm{~mm}$ sedangkan pada tiang bor dengan pembesaran menggunakan diameter selimut tiang sebesar $1200 \mathrm{~mm}$ dan diameter bel sebesar $1600 \mathrm{~mm}$. Hasil analisis dan perbandingan daya dukung tiang diameter sedang dapat dilihat pada tabel 8 .

Tabel 8. Hasil analisis dan perbandingan daya dukung tiang diameter besar

\begin{tabular}{ccccc}
\hline Jenis tiang & $\begin{array}{c}\text { Volume beton } \\
\left(\mathrm{m}^{3}\right)\end{array}$ & $\begin{array}{c}\text { Daya dukung } \\
(\mathrm{kN})\end{array}$ & $\begin{array}{c}\text { \% Daya dukung } \\
\text { tercapai }\end{array}$ & $\begin{array}{c}\text { \% Beton yang } \\
\text { digunakan }\end{array}$ \\
\hline $\begin{array}{c}\text { Tiang Tanpa Pembesaran } \\
\text { Belled Pile (Pembesaran di } \\
\text { tengah tiang) }\end{array}$ & 54,29 & 4909,64534 & 100,0 & 100 \\
Belled Pile (Pembesaran di & 30,62 & 3914,013 & 79,7 & 56,4 \\
$\begin{array}{c}\text { ujung tiang) } \\
\text { Multi-Belled Pile }\end{array}$ & 30,62 & 4909,620 & 91,2 & 56,4 \\
\hline
\end{tabular}

\section{Hasil perbandingan}

Pada belled pile (pembesaran di tengah tiang) peningkatan daya dukung tiang untuk kategori ukuran diameter kecil, sedang dan besar adalah sebesar 3,3\%, 6,4\% dan 13\%. Perbandingan belled pile (pembesaran di tengah tiang) dengan tiang bor tanpa pembesaran dengan diameter sebesar D pada kategori tiang ukuran diameter kecil, diameter sedang dan diameter besar menunjukkan persentase daya dukung sebesar 77,2\%, 77,9\% dan 79,7\%. Hal ini dikarenakan konsistensi tanah pada kedalaman 12 meter kurang keras dan kekuatan ujung tiang hanya diperoleh dari selisih diameter bel dan diameter selimut tiang.

Pada belled pile (pembesaran di ujung tiang) peningkatan daya dukung tiang untuk kategori ukuran diameter kecil, sedang dan besar adalah sebesar 7\%, 13,9\% dan 29,2\%. Perbandingan belled pile (pembesaran di ujung tiang) dengan tiang bor tanpa pembesaran dengan diameter sebesar D pada kategori tiang ukuran diameter kecil, 
diameter sedang dan diameter besar menunjukkan persentase daya dukung sebesar 80\%, 83,5\% dan 91,2\%. Hal ini dikarenakan konsistensi tanah pada kedalaman 27 meter sangat keras dan kekuatan ujung tiang diperoleh tanpa mengurangi diameter bel dan diameter selimut tiang.

Pada multi-belled pile peningkatan daya dukung tiang untuk kategori ukuran diameter kecil, sedang dan besar adalah sebesar 10,3\%, 20,2\% dan 42,5\%. Perbandingan multi-belled pile dengan tiang bor tanpa pembesaran dengan diameter sebesar D pada kategori tiang ukuran diameter kecil, diameter sedang dan diameter besar menunjukkan persentase daya dukung sebesar $82,5 \%, 88,1 \%$ dan $100,5 \%$. Hal ini dikarenakan pada multi-belled pile mendapatkan daya dukung dari pembesaran yang ada di tengah tiang dan pembesaran yang ada di ujung tiang.

\section{KESIMPULAN DAN SARAN}

\section{Kesimpulan}

Berdasarkan hasil analisis dan pembahasan daya dukung tiang maka dapat disimpulkan bahwa:

1. Belled Pile dan Multi-Belled Pile terbukti mampu meningkatkan daya dukung secara efektif. Dimana daya dukung belled pile dan multi-belled pile meningkat dengan hanya meningkatkan volume beton yang digunakan kurang dari $4 \%$.

2. Pada belled pile (pembesaran di tengah tiang), peningkatan ukuran tiang dari diameter kecil, diameter sedang sampai diameter besar dapat berpengaruh pada persentase daya dukung tercapai. Pada tiang diameter kecil daya dukung tercapai adalah $103,3 \%$, pada tiang diameter sedang daya dukung tercapai adalah $106,4 \%$ dan pada tiang diameter besar daya dukung tercapai adalah $113 \%$.

3. Pada belled pile (pembesaran di ujung tiang), peningkatan ukuran tiang dari diameter kecil, diameter sedang sampai diameter besar meningkatkan persentase daya dukung tercapai. Pada tiang diameter kecil daya dukung tercapai adalah $107 \%$, pada tiang diameter sedang daya dukung tercapai adalah $113,9 \%$ dan pada tiang diameter besar daya dukung tercapai adalah $129,2 \%$.

4. Pada multi-belled pile, peningkatan ukuran tiang dari diameter kecil, diameter sedang sampai diameter besar meningkatkan persentase daya dukung tercapai. Pada tiang diameter kecil daya dukung tercapai adalah $110,3 \%$, pada tiang diameter sedang daya dukung tercapai adalah 120,2\% dan pada tiang diameter besar daya dukung tercapai adalah $142,5 \%$.

5. Belled Pile (pembesaran di ujung tiang) lebih efektif dibandingkan dengan Belled Pile (pembesaran di tengah tiang). Hal ini dapat dilihat dengan membandingkan persentase daya dukung tercapai dan volume beton yang digunakan. Belled Pile (pembesaran di ujung tiang) memiliki daya dukung lebih besar dibandingkan dengan Belled Pile (pembesaran ditengah tiang) meskipun volume beton yang digunakan sama.

6. Multi-Belled Pile memiliki peningkatan daya dukung paling besar dibandingkan dengan belled pile. Dimana peningkatan daya dukung belled pile pada kategori ukuran tiang diameter kecil, sedang dan besar adalah $10,3 \%, 20,2 \%$ dan 42,5\% sedangkan pada belled pile (pembesaran di ujung tiang) adalah sebesar $7 \%, 13,9 \%$ dan $29,2 \%$.

7. Pada kategori ukuran tiang diameter kecil dan sedang, belled pile dan multi-belled pile dengan diameter sebesar D dan diameter selimut sebesar 3/4 D tidak mampu mencapai daya dukung tiang bor tanpa pembesaran dengan diameter sebesar D. Belled pile (pembesaran di tengah tiang) mempunyai persentase daya dukung tercapai sekitar $77 \%$. Belled pile (pembesaran di ujung tiang) memiliki persentase daya dukung tercapai $80 \%$ dan $83,5 \%$. Multi-belled pile memiliki persentase daya dukung tercapai sebesar $82,5 \%$ dan $88,1 \%$. Dengan volume beton yang digunakan pada ketiga jenis tiang tersebut sekitar $56 \%$.

8. Pada kategori ukuran tiang diameter besar, hanya multi-belled pile dengan diameter sebesar D dan diameter selimut sebesar 3/4 D mampu mencapai daya dukung tiang bor tanpa pembesaran dengan diameter sebesar D. Belled pile (pembesaran di tengah tiang) memiliki persentase daya dukung tercapai sekitar 79,7\%. Belled pile (pembesaran di ujung tiang) memiliki persentase daya dukung tercapai 91,2\%. Sedangkan multi-belled pile memiliki persentase daya dukung tercapai sebesar $100,5 \%$. Dengan volume beton yang digunakan pada ketiga jenis tiang tersebut sekitar $58 \%$.

\section{Saran}

Dari hasil penelitian yang telah dilakukan, penulis memberikan beberapa saran untuk melengkapi kekurangankekurangan yang ada, antara lain:

1. Melakukan analisis daya dukung menggunakan software sebagai pembanding hasil analisis yang telah dilakukan.

2. Perlu adanya data hasil uji laboratorium secara lengkap agar parameter tanah lebih spesifik dan hasil analisis menjadi lebih akurat. 
3. Melakukan analisis terhadap perilaku daya dukung pembesaran tiang pada tiang kelompok.

\section{DAFTAR PUSTAKA}

Bowles, Joseph E. Analisa dan Desain Pondasi Jilid 1. Penerj. Pantur Silaban. 5th. Jakarta: Penerbit Erlangga, 1996.

Franki Foundations. https://www.ffgb.be/en/techniques/piles/large-diameter-bored-piles/large-diameter-boredpile-with-enlarged-base. t.thn. 6 February 2020.

Honda, T., Yoshio Hirai dan Eiji Sato. "Uplift Capacity Of Belled And Multi-Belled Piles In Dense Sand." SOIL AND FOUNDATIONS 51.3 (2011): 483-496.

Kong, Gangqiang. "Performances Of Compressive Capacity for Belled Wedge Pile Group." Advance Material Research 261-263 (2011): 1084-1088.

Lin, J., Shih-Yu Hsu dan San-Shyan Lin. "The New Method to Evaluate The Uplift Capcity of Belled Pile in Sandy Soil." Journal of Marine Science and Techonology 23.4 (2015): 523-533.

Naval Facilities Engineering Command. Foundations \& Earth Structures Design Manual 7.2. Virginia, 1986.

Prakash, Shamsher dan Hari D. Sharma. Pile Foundation In Engineering Practice. Wiley, 1990.

Yang, B., dkk. "Uplift Behavior of Belled Short Pile in Weathered Sandstone." Mathematical Problems in Engineering Volume 2018 (2018): 1-8. 